\title{
The historical evolution of the concept of apoptosis in rheumatic diseases
}

\section{Evoluzione storica del concetto di apoptosi nelle malattie reumatiche}

\author{
A.A. Conti ${ }^{1,2}$, D. Lippi ${ }^{3}$, G.F. Gensini ${ }^{1,2}$ \\ ${ }^{1}$ Department of Critical and Surgical Health Care, University of Florence, Florence; \\ ${ }^{2}$ Don Carlo Gnocchi Foundation, IRCCS Florence; \\ ${ }^{3}$ Department of Anatomy, Histology and Legal Medicine, University of Florence, Florence
}

\begin{abstract}
RIASSUNTO
Anche se il concetto di apoptosi può essere probabilmente rintracciato per la prima volta in un trattato ippocratico, fu Rudolph Virchow, il padre della patologia cellulare, a dare la prima descrizione strutturata, nel XIX secolo, dei processi sottostanti il termine apoptosi.

Nel corso del XX secolo è stato costruito un patrimonio di osservazioni sistematiche riguardanti la morte cellulare. Nel 1908 Mechnikov vinse il Premio Nobel per i suoi studi sulla fagocitosi, mentre negli anni '30 e '40 furono condotti molti studi sulla metamorfosi, e Fell e Canti individuarono la morte cellulare in condrociti in cultura. Alla fine degli anni '40 Saunders diede inizio alle sue osservazioni sulla morte cellulare negli arti del pulcino, e Hamburger e Levi Montalcini avviarono le loro ricerche sui fattori di crescita nervosa. Intorno alla metà degli anni'50 cominciò lo studio dei lisosomi, e negli anni '60 Kerr defini la necrosi da contrazione. Il termine apoptosi fu introdotto e diffuso definitivamente dallo stesso Kerr nel 1972 per indicare una particolare forma di morte nella quale le cellule si suicidano disgregandosi in corpi apoptotici legati alle membrane. Negli anni '80 fu descritto il ced-3 ed all'inizio degli anni '90 furono identificati i geni dell'apoptosi.

Più recentemente nuovi strumenti hanno consentito la descrizione di un ampio spettro di morte cellulare, compresa l'apoptosi modernamente intesa. Il suo ruolo e la sua funzione in molte malattie differenti appare oggi di notevole interesse, ed in particolare in quelle reumatiche evidenze recenti suggeriscono che, lungi dall'essere un percorso semplice, breve e monomorfico, l'apoptosi è al contrario un processo complesso, lungo e pleiomorfico.
\end{abstract}

Reumatismo, 2005; 57(1):57-61

\section{HISTORICAL BACKGROUND (BEFORE THE XX CENTURY)}

Tiens he concept of "apoptosis" can be found in chapter 35 of Hippocrates' Mochlicon (V-IV century B.C.), a treatise concerning the reduction of dislocations, in which the gangrene resulting from the treatment of fractures by means of bandages is reported and described $(1,2)$. The idea of apoptosis was consequently already implied by Hippocrates to indicate what today is considered the phy-

Indirizzo per la corrispondenza:

Dott. Andrea Alberto Conti

Department of Critical and Surgical Health Care,

University of Florence

Viale Morgagni 85

I-50134, Florence, Italy

E-mail: <aa.conti@dac.unifi.it> siological destruction of cells and tissues. Areteus of Cappadocia in the I century A.D. and Galen of Pergamus in the II gave ulterior and better elaboration to the concept of "necrosis", and the term was fully defined by Rudolph Virchow, the great German pathologist, in the XIX century (3). In 1858 , in his 15 th lecture, Virchow described two types of cell death, necrobiosis and necrosis. Necrobiosis is "always here to deal with a gradual decay and death, a dissolution... Necrobiosis is death brought on by (altered) life, a spontaneous wearing out of living parts, the destruction and annihilation consequent on life, natural as opposed to violent death (mortification)... But the idea of necrosis really does not offer any analogy to these processes" $(4,5)$. In effect, Virchow called necrobiosis what we today call apoptosis, specifically distinguishing it from true necrosis; he applied the term 
necrosis to a specific type of cell degeneration, whose fundamental characteristic was a striking tissue collapse accompanied nevertheless by the maintenance of the outer form of the dead tissues. Instead, he adopted the term necrobiosis from Schultz (6), to describe cell degeneration in those cases in which it was impossible to identify the previous structure of the tissues involved. In Virchow's view, in the presence of necrobiosis, cells undergo a process of tissue softening and disintegration with the consequence that the "mortified section" completely disappears, and may only be repaired by its replacement from nearby tissues. What Virchow termed a softening of tissues is today retained to be the result of the action of cellular enzymes which cause the colliquative necrosis of dead tissues. His two descriptions of cell death, necrosis and necrobiosis, currently fit the models of limb gangrene and of brain colliquative necrosis respectively.

The word apoptosis has been found cited in a XIX century Spanish medical dictionary by FernandezFlores and coworkers $(2,7)$, and at the end of the XIX century different types of cell death were observed, even if many scientists seemed to be more interested in phagocytosis than in necrobiosis or apoptosis (8).

Julius Cohnheim was the author of the successive description of cellular death (9); taking into account the observations performed by Carl Weigert by means of the light microscope (10) he introduced the term coagulation necrosis. Weigert had discovered a notable fibrin impregnation in the epithelium of the trachea and the bronchi of patients with diphtheria, even if it was later demonstrated that the fibrin component was not related to tissue coagulation. The research of Weigert determined a massive increase in the studies on cell death, and in the last decade of the XIX century a number of other terms were used, so as to adapt language to the new pathological conditions, thus contributing to the detection of the different characteristic features of nuclear necrotic degeneration, such as karyolysis and karyorrhexis. By means of a camera lucida, in 1885 Flemming was able to identify a specific type of the alteration of nuclei, naming it "chromatolysis", since it dealt with the rupture and the following disappearance of the cells of the regressive ovarian follicle. Flemming accurately described the presence of half moons of heterochromatin along the nuclear envelope, and the successive rupture of nuclei surrounded by a rim of cytoplasm in the cavity of the follicle (11).
Flemming's observations are still today included among the first descriptions of the modifications typical of apoptotic cell death.

\section{CENTURY DEVEOPMENTS}

Nowadays the field of apoptosis is one of the most studied in biology and medicine and accounts for more than $2 \%$ of all life science publications annually (12). Currently the term apoptosis refers to a special morphology in which chromatin condenses or coalesces to heterochromatin in one or more masses in the nucleus; it usually settles along the still intact nuclear membrane (8). This definition derives from a long process of research carried out during the XX century, and whose major achievements have permitted the knowledge we have today.

In spite of the major results of the XIX century in the context of necrosis and necrobiosis, to use Virchow's terms, at the beginning of the XX century cell death continued to remain a topic of interest only in such closed fields as insect physiology. However, Ilya Mechnikov won the Nobel Prize in 1908 for his discovery of phagocytosis, while in 1910 Charles Pérez published a treatise on the metamorphosis of the blowfly Calliphora erythrocephala, underlining his conviction that the larva were destroyed by phagocytes (13).

The studies of Graeper in 1914, focusing on the development of the yolk sac, established the need for the presence of chromatolysis in the cells that were to be deleted, disclosing that neighbouring cells were able to absorb the cell debris (14). However, the term chromatolysis remained in the use of the period, since the relevant confirmation by Graeper was not appropriately appreciated by the scientific community; in particular neuropathologists continued to adopt the same term in order to describe a completely different condition, represented by the apparent collapse of Nissl substance after the transection of the axon.

In effect in the first years of the XX century the attempts to define the mechanisms of cell death were still neither numerous nor systematic in their methodological approach. The systematists tried to catalogue deaths in an effort to derive scientific meaning from the large amount of confused data available, until Glucksmann (15) described in an organic way different types of cell death, among them nuclear fragmentation (karyorrhexis) and the apoptotic appearance of nuclei (karyopyknosis). 
Glucksmann also recognized that cell death was useful not only from the perspective of histiogenetic and phylogenetic developments, but from morphogenetic ones as well.

In the middle fifties, De Duve discovered the lysosomes, and this achievement led the researcher to propose that cells may die by means of the explosion of their lysosomes (16). The studies of De Duve were very relevant in the perspective of a better comprehension of the existence of additional, non-accidental types of cell demise.

During the sixties the embryologist J.W. Saunders identified reproducible patterns of cell death in chick embryos, while different insect physiologists started the examination of metamorphic cell deaths occurring after pupation (17). Saunders had reported the presence of a posterior necrotic area in the axilla of chick limbs and he demonstrated that explanted posterior necrotic area cells would die on schedule in culture. However, they could be saved if transplanted to the back of different chick embryos, thus suggesting the availability of a controlled regulation of cell death. During the same period, R.A. Lockshin began to refer to "programmed cell death", with the meaning that cells had a sequence of highly regulated steps towards their own destruction (8), and both Saunders's and Lockshin's discoveries made the possibility of control of cell death a reality; afterwards, they focussed on the fact that cells remained functional in the early part of their involution.

\section{APOPTOSSAND RHEUMATC DISEASES}

In 1972 J.F.R. Kerr introduced the term apoptosis to indicate a mechanism of "controlled cell deletion", which seemed "to play a complementary but opposite role to mitosis in the regulation of animal cell population" (18). In Kerr's view this mode of cell death foresaw two different phases, represented by the degradation of the nucleus and the cytoplasm into apoptotic bodies bound to the membranes and by the subsequent assimilation of these same bodies on the part of other cells. Apoptosis appeared to occur in different processes, among them the physiologic development of embryos and the loss of cells in the course of tumoral growth. Kerr underlined the function of the socalled "intrinsic clock", contemporaneously proposing the role of a genetic element in the process and correctly estimating the relevance of environment in the regulation of apoptosis. A ge- netic program was therefore retained to be present both in the so-called "programmed cell death" and in the apoptosis process, and this fact sometimes generated misunderstanding in the use of the two expressions. It has consequently recently been pointed out that the term apoptosis ought to be used to describe a situation in which the tools for instant suicide are well defined and specified, while "programmed cell death" should be used to indicate a death on schedule in which the time to/of death is specified (19).

In effect in the course of time the different authors researching in the cell death field have elaborated a paradigm shift, switching from one in which apoptosis and necrosis were considered well distinguished types of cell demise from a morphological and biochemical standpoint, to one in the context of which the two cell death modalities are an integral part of a same spectrum of cell death, sharing common characteristics. In this recent approach "pure" necrosis and "pure" apoptosis are the extremes of a continuous array of aponecrotic responses, and it should be stressed that a blend of characteristics related to both necrosis and apoptosis constitutes the far more usual response of tissues and cells to damaging stimuli. The consequence of such an integrated system and view is that this new concept of cell death in apoptosis has major implications both for the full comprehension of the physiologic patterns of apoptosis, and for its deranged manifestations, the latter prompted by its deregulation in human pathology (20), and, in particular, in rheumatic diseases. In this area basic research in apoptosis has concentrated on three major features: the selection of new lymphocytes before antigen challenge; the control of clonal expansion and resolution, with the incorporation of the destruction of apoptotic cells; the selection of memory cells $(21,22)$.

With regard to systemic lupus erythematosus, multiple defects in the clearance of apoptotic material have been demonstrated, and many authors therefore suggest that failure of clearance is at the heart of the pathology (23). In effect diminuished clearance of dying cells on the part of macrophages, together with augmented apoptosis, determine an accumulation of cellular fragments in many different tissues. This process appears to provoke the uptake of autoantigens from apoptotic nuclei by dendritic cells. These cells then display modified self-epitopes to naïve T cells, and, consequently, autoreactive $\mathrm{T}$ cells become activated. These furnish help for B cells which present 
peptides processed from the recent apoptotic attack. Insufficient phagocytic removal of early apoptotic cells can determine an accumulation of necrotic cells and debris in the germinal centers of secondary lymph organs. Furthermore B cells may come into contact with intracellular autoantigens released during the late stages of apoptotic cell death and may become immobilised by follicular dendritic cells.

With reference to osteoarthritis, a number of recent studies have demonstrated that apoptotic cell death takes place at an increased rate in osteoarthritic cartilage (24). Even if researchers must still undertake hard work to understand the mechanisms underlying the process of complete cell death in cartilage destruction, a satisfactory level of comprehension of the extent of cell death in the pathologic process has already been achieved, and in this context apoptotic phenomena appear to be consistent and relevant.

In rheumatoid arthritis a full understanding of the mechanisms involved in the resistance to apoptosis of synovial macrophages and fibroblasts is mandatory to elucidate the processes that contribute to the perpetuation of the disease, as well as to trace targets for new and effective therapies. Whether apoptosis in rheumatoid arthritis is a friend or foe is still unclear at present (25); however, to prevent pharmacological toxicity, which is also prompted by the triggering of apoptosis, the patterns of expression of the latter need to be carefully identified and explained.

Recent studies suggest that one of the pathologic cascades that lead to damage related to SSA/RoSSB/La-associated congenital heart block can be initiated by means of apoptosis resulting in the translocation of SSA/Ro-SSB/La antigens with consequent surface binding by maternal autoantibodies (26). The eccessive apoptosis observed in autopsy slides from fetuses with congenital heart block may effectively provide an essential clue to the understanding of the pathogenicity of maternal autoantibodies.

In summary, in rheumatic diseases, differently from other clinical pathological conditions, cell death, far from being the end of pathologies, often constitutes their beginning (27). Recent data in rheumatology provide evidence that cell death is a long-lasting, complex and pleiomorphic process, during which cells gain novel functions and activities, initiating (auto)immunological events provoking disease. An overview on apoptotic cells in rheumatic pathologies therefore provides a new stimulating perspective on "life" and "death" in the course of pathological processes, since the presence of dead cells, rather than the absence of living cells, is, in these cases, fundamental for pathogenesis.

\section{CONCLUSIONS}

The historical evolution of the concept of apoptosis appears stimulating because many "different" phases of its history have followed each other in time and each of them has been related to a specific stage of knowledge. Even if the idea of apoptosis may probably be detected as far back as in a Hippocratic treatise, it was only Rudolph Virchow in the XIX century who gave the first structured description of the processes underlying the term (28), while in the course of the XX century a body of systematic observations was elaborated on cell death in an organic way: from the studies of Mechnikov on phagocytosis to the research of Fell and Canti on metamorphosis, from the observations of Saunders on cell death in chick limbs to Deduve's studies on lysosomes, from Hamburger's exploration of nerve growth factors to the definition of shrinkage necrosis by Kerr. In very recent times new instruments have permitted the description of a wide range of cellular death, including apoptosis as currently defined. Its role and function in many different pathologies appear of specific interest; in particular, in rheumatic diseases, extremely recent evidence indicates that, far from being simple, brief and monomorphic, apoptosis is a complex, longlasting, and pleiomorphic process.

\section{Acknowledgements}

The Authors would like to thank Professor Luisa Camaiora, B.A., M.Phil., for her correction of the English. 


\section{SUMMARY}

Even if the idea of apoptosis may probably be detected for the first time in a Hippocratic treatise, it was Rudolph Virchow, the founder of cellular pathology in the XIX century, who gave the first structured description of the processes underlying the term. In the course of the XX century a body of systematic observations on cell death was elaborated in an organic way. In 1908 Mechnikov won the Nobel Prize for his studies on phagocytosis, while in the '30s and " 40 s many studies on metamorphosis were carried out, and Fell and Canti identified cell death in chondrocytes in culture. At the end of the "40s Saunders began to observe cell death in chick limbs, and Hamburger and Levi Montalcini began their exploration of nerve growth factors. In mid ' 50 s research on lysosomes began, and in the " 60 s Kerr defined shrinkage necrosis. The term apoptosis was definitely introduced by Kerr in 1972 to indicate a particular form of death in which cells commit suicide by dissolving themselves into membrane-bounded apoptotic bodies. In the ' 80 s ced-3 was described and at the beginning of the 90 s apoptosis genes were identified.

In more recent times new instruments have allowed a wide range of cellular deaths to be described, including apoptosis as currently defined. Extremely interesting are its role and function in many different diseases; in particular in rheumatic ones recent evidence indicates that, far from being simple, brief and monomorphic, apoptosis is a complex, long-lasting, and pleiomorphic process.

Key words - Apoptosis, necrosis, rheumatic diseases, history of medicine.

Parole chiave - Apoptosi, necrosi, malattie reumatiche, storia della medicina.

\section{REFRENCES}

1. Linné E. Oeuvres complètes d'Hippocrate. Paris: Edition JH Baillière, 1939.

2. André N. Hippocrates of Cos and apoptosis. Lancet 2003; 361: 1306.

3. Gerschenson LE, Jon Geske F. Virchow and apoptosis. Am J Pathol 2001; 158: 1543.

4. Virchow R. Die Cellularpathologie in ihrer Begruendung auf physiologisher und pathologischer Geweblehre. Berlin, 1858.

5. Virchow R. Cellular pathology. Translated by F. Chance. New York: Dover Publications, 1971.

6. Schultz KH. In: Virchow, Spec. Pathol und Therap, 1858, I. 273-9.

7. Fernandez-Flores A, Aguilera B, Yau P, Oliva H. An old meaning of the word apoptosis. Lancet 2002; 359: 1072.

8. Lockshin RA, Zakeri Z. Programmed cell death and apoptosis: origins of the theory. Nature Rev 2001; 2: 545-50.

9. Cohnheim J. Lectures on cellular pathology. Sect. II, ed. 2, translated from German by $\mathrm{AB}$ McKee, London, 1889.

10. Weigert C. Über Croup und Diphteritis, II Teil. beobachtungen beim Menschen, Virchows Archiv Pathol Anat 1877; 72: 218-257.

11. Flemming W. Über die Bildung von Richtungsfiguren in Saeugerthiereiern beim Untergang Graaf'sscher Follikel, Archiv f Anat u Physiol. Anat Abteilung 1885: 221-44.

12. Curtin JF, Cotter TG. Apoptosis: historical perspectives. Essays Biochem 2003; 39: 1-10.

13. Pérez C. Recherches histologiques sur la métamorphose des muscides (Calliphora erytrocephala Mg). Arch Zool Exper Gen 5e Série 1910; 4: 1-274.

14. Graeper L. Eine neue Anschauung ueber physiologische Zellausschaltung, Arch Zellforschung 1914; 2: 373-94.
15. Glucksmann A. Cell deaths in normal vertebrate ontogeny. Biol Rev Camb Phil Soc 1951; 26: 59-86.

16. Majno G, Joris I. Cells, tissues and disease: principles of general pathology. Boston, 1994.

17. Saunders JW Jr. Death in embryonic systems. Science 1966; 154: 604-12.

18. Kerr JFR, Wyllie AH, Currie AR. Apoptosis: a basic biological phenomenon with wide-ranging implications in tissue kinetics. Br J Cancer 1972; 26: 239-57.

19. Majno G, Joris I. Apoptosis, oncosis and necrosis. An overview on cell death. Am J Pathol 1995; 146: 3-15.

20. Formigli L, Zecchi Orlandini S, Capaccioli S, Poupon M-F, Bani D. Energy-dependent types of cell death in MCF-7 breast cancer cell tumors implanted into nude mice. Cells Tissues Organs 2002; 170: 99-100.

21. Salmon M, Gordon C. The role of apoptosis in systemic lupus erythematosus. Rheumatology 1999; 38 : 1177-83.

22. Lockshin RA, Williams CM. Programmed cell death. Endocrine potentiation of the breakdown of the intersegmental muscles of silkmoths. J Insect Physiol 1964; 10: 643-9.

23. Sheriff A, Gaipl US, Voll RE, Kalden JR, Herrmann M. Apoptosis and Systemic Lupus Erythematosus. Rheum Dis Clin N Am 2004; 30: 505-27.

24. Aigner T, Kim HA, Roach HI. Apoptosis in Osteoarthritis. Rheum Dis Clin N Am 2004; 30: 639-54.

25. Liu H, Pope RM. Apoptosis in Rheumatoid Arthritis: friend or foe. Rheum Dis Clin N Am 2004; 30: 505-27.

26. Clancy RM, Buyon JP. More to death than dying: apoptosis in the pathogenesis of SSA/Ro-SSB/La-associated congenital heart block. Rheum Dis Clin N Am 2004; 30: 589-602.

27. Pisetsky DS. Apoptosis in the rheumatic diseases. Rheum Dis Clin N Am 2004; 30: xiii-xiv.

28. Formigli L, Conti AA, Lippi D. "Falling leaves": a survey of the history of apoptosis. Minerva Med 2004; 95 : 159-64. 